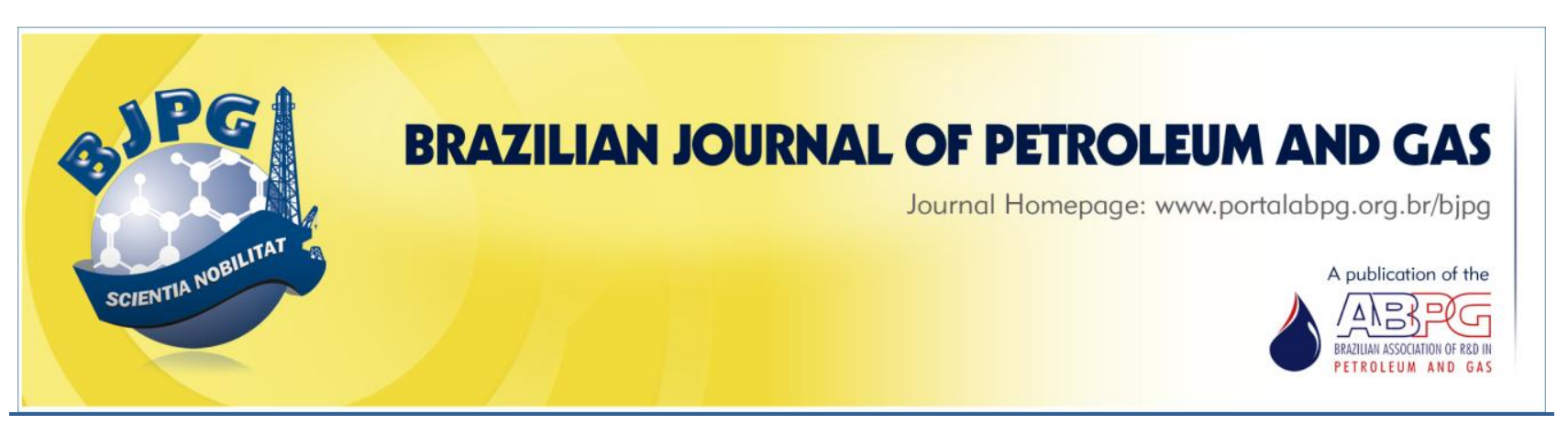

\title{
EFFECT OF AGEING ON POROSITY OF HOT MIX ASPHALT
}

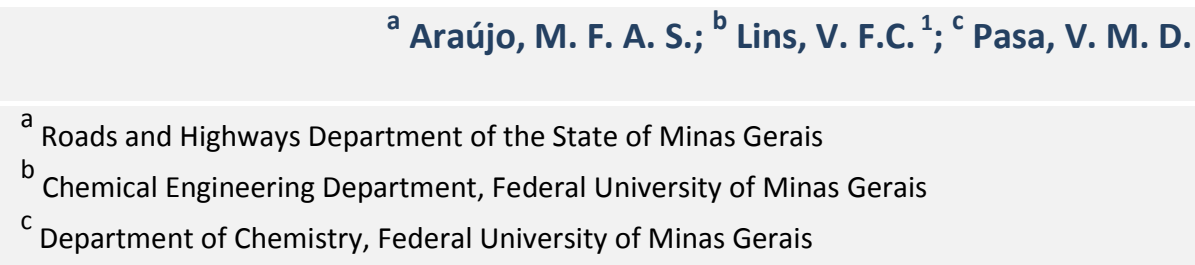

\section{ABSTRACT}

Asphalt ageing due to the action of solar radiation must be considered in the study of the performance of asphalt pavement, especially in Brazil because of its geographical characteristics. The aim of this work is to study asphalt ageing caused by the effect of xenon radiation, by using weathering tests. Sample degradation was evaluated by using Fourier transform infrared spectroscopy (FTIR). The results of FTIR indicated an oxidation process of the material, which occurred during exposure in the xenon arc chamber. The area ratio related to the bands of the aliphatic $\mathrm{CH} / \mathrm{OH}$ and $\mathrm{CH} / \mathrm{C}=\mathrm{O}$ groups and those of the $\mathrm{Si}-\mathrm{O}-\mathrm{Si} / \mathrm{OH}$ groups of bitumen decreased after exposure to xenon radiation. The samples were analyzed by using $X-$ ray fluorescence (XRF) and scanning electron microscopy (SEM). The porosity of the samples before and after ageing was measured by using the SEM micrographs and the image software Quantikov.

\section{KEYWORDS}

Asphalt; ageing; xenon radiation; infrared spectroscopy; porosity; image analysis

\footnotetext{
${ }^{1}$ To whom all correspondence should be addressed.

Address: Chemical Engineering Department, Federal University of Minas Gerais, Belo Horizonte - MG, Brazil Telephone/Fax: +55 31 3409-1775/+55 31 3409-1789 |e-mail:vlins@deq.ufmg.br doi:10.5419/bjpg2011-0002
} 


\section{INTRODUCTION}

Brazil has more than $168,000 \mathrm{~km}$ of asphaltpaved highways. At the present time, $26 \%$ of the highways in the State of Minas Gerais in Brazil are damaged. One of the requirements for Brazil's sustainable development is the improvement in the quality of its highways. The expected service life of highways in Brazil is ten years, but, in general, the pavement does not last for so long.

One of the main causes of the current level of degradation is the drastic reduction in public investment in the conservation of roads and highways. Another cause is excess weight per truck axle, which occurs on almost all national highways that do not have weighing stations for heavy vehicles (Cortizo, 2004). The effects of the overweight are manifested by well-known phenomena, one of which is the accelerated fatigue of bituminous pavement overlays and the lower layers with higher hardness.

Asphalt binder is the main material used for paving in Brazil which undergoes ageing process during its processing, application, and service life. Asphalt ageing involves a number of physical and chemical processes over the life of the pavement (Tonial, 2001) and has several causes. The main cause is oxidation, which results in an increase in consistency of asphalt binder as well as loss of volatiles. (Leite, 1999). The exaggerated increase of the consistency, especially in heavy traffic conditions, can significantly decrease the lifetime of the pavement. Another cause is moisture, which is usually manifested by loss of cohesion of the mixture and loss of adhesion between bitumen and the aggregate interface (stripping) (Airey, 2003).

The ageing of asphalt binder due to sun ultraviolet radiation is one of the factors responsible for the decrease in the pavement's useful life. This parameter is very important in Brazil due to its latitude, and consequent high level of sun radiation.

In the United States, from 1987 to 1993, the Strategic Highway Research Program (SHRP) developed new specifications and tests for asphalt materials. The SUPERPAVE system introduced new rheological tests such as the Rolling Thin Film Oven Test, according to the ASTM D2872, and the Pressure Aging Vessel test, according to the ASTM D6521 (Whiteoak, 1990). However, the effect of solar radiation was not taken into consideration.

The influence of solar radiation on degradation of asphalt binder has been known since 1822, but this influence has been ignored in simulations of asphalt ageing in laboratories since it has been found that, due to the high absorption coefficient of radiation of bitumen, solar radiation affects only the top layers of asphalt pavement (Airey, 2003).

A recent study (Durrieu et al, 2007) reports that the influence of ultraviolet radiation on the ageing of the upper layers of asphalt pavement cannot be ignored since the degradation is fast. After 10 hours of exposure to ultraviolet radiation the asphalt binder reaches oxidation levels similar to those achieved after being submitted to the Pressure Ageing Vessel (PAV) test, the Rolling Thin Film Oven Test (RTFOT), or after one year of exposure to solar rays.

In terms of functional groups, the oxidative ageing process is associated with increased content of carbonyl and hydroxyl groups and sulfoxides in the asphalt binder, which can be identified using Fourier Transform Infrared Spectroscopy (Huet, 1988; Lins and Araujo, 2008; Lins et al., 2008).

The aim of this study is to evaluate the effect of ageing on the porosity of hot mix asphalt, which it is not found in the literature. The ageing of asphalt binder in asphalt mixture was performed in chambers with cycles of xenon radiation and moisture. The degradation was evaluated by using scanning electron microscopy (SEM), image analysis using the imaging software Quantikov (Arenas et al., 2008; Vasconcelos et al., 2002), Xray fluorescence spectroscopy (XRF) and X-ray diffraction (XRD).

\section{MATERIALS AND METHODS}

The asphalt binder was provided by PETROBRAS and was certified by using the following tests:

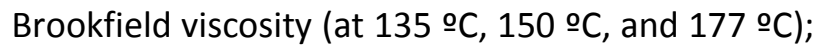
penetration $100 \mathrm{~g}, 5 \mathrm{~s}, 25 \stackrel{\circ}{\circ}$, according to the ASTM D 5 Standard; softening point; flash point (으), according to the ASTM D 92 Standard; ductility at 25ㅇ, according to the ASTM D 113 Standard; solubility (\% wt/wt) in trichloroethylene, according to the ASTM D 2042 Standard; and relative density. 
The hot mix asphalt (HMA) samples were obtained by using $5.4 \mathrm{wt} \%$ of asphalt binder provided by PETROBRAS, $47.3 \mathrm{wt} \%$ crushed rock, $37.8 \mathrm{wt} \%$ rock powder, and $9.5 \mathrm{wt} \%$ sand, according to the Marshall method (ASTM D6926). The maximum diameter of the crushed rock particles was $12.5 \mathrm{~mm}$, with a thinness modulus of 5.74 and a Los Angeles abrasion of 42 wt \% (Bernucci et al., 2008).

The asphalt binder was submitted to the ASTM D 2872 (RTFOT - Rolling Thin Film Oven Test) before the ageing test. Hot mix asphalt (HMA) samples were exposed in the weather-O-meter, Atlas $\mathrm{Cl} 65$, performing cycles of 80 minutes: $64 \mathrm{~min}$ of exposure to radiation and $16 \mathrm{~min}$ of radiation with water spray. The temperature in the chamber was $60{ }^{\circ} \mathrm{C}$ and irradiation was set at $340 \mathrm{~nm}$ (or $0.35 \mathrm{~W} / \mathrm{m}^{2}$ ), according to ASTM D 4798, using a variable power range (3500-6500 W) to maintain the intensity of irradiation. The samples were exposed for up to 2000 hours.

The equipment used for the infrared analysis was an ABB Bomem spectrometer, Model MB102, and spectra were obtained in units of absorbance in the interval of 4000 to $400 \mathrm{~cm}^{-1}$, registered with 64 accumulations and resolution of $4 \mathrm{~cm}^{-1}$, on a $\mathrm{KBr}$ pellet or as a thin film on a $\mathrm{KBr}$ cell. The calculation of peak area was performed by using the PeakFit Program with line correction of linear base. For the production of a thin film, the sample was dissolved in $\mathrm{CHCl}_{3}$ and deposited on a $\mathrm{KBr}$ cell.

Chemical analysis by X-ray semi quantitative fluorescence spectroscopy (XRF) was performed using PHILIPS PW-2400 spectrometer; the samples were comminuted and pressed into pellets using boric acid as a binder.

A PHILIPS X-Ray diffractometer for powder samples (PANALYPTICAL) with an X'Pert-APD system was used, with a PW 3710/31 controller, a 1830/40 PW generator and a PW 3020/00 goniometer for testing $\mathrm{X}$-ray diffraction.

The hot mix asphalt samples were metalized by using a Denton Vacuum Desk model II equipment and three layers of gold were plated to prevent volatilization of organic material during the SEM test.

The scanning electron microscope used was a JEOL, JSM 5410 model, with a 15-kV tungsten filament, operating at a vacuum of $10^{-4}$ Pascal.

The SEM micrographs were treated by the software Quantikov to determine the porosity of the plates of asphalt mixture with and without exposure in the weathering chamber. The software Quantikov (Vasconcelos et al, 2002) consists of an analyzer that performs a micro structural digital processing of images, quantifies and generates geometric graphs. The Quantikov uses its own methods for obtaining geometric parameters, combining images with stereometric analyzers that compose the quantification methods. The main module implements the Saltykov method, which assumes spherical grains and pores to the method of Jensen \& Gundersen (sampling points), making no assumptions about the geometric shape of microelements. There is also a method for evaluating the average intercept grains with discontinuous contours, providing a graphic display of measurements and facilitating their statistical treatment.

\section{RESULTS AND DISCUSSIONS}

\subsection{Characterization of the asphalt binder}

The results of the characterization of the asphalt binder are shown in Table 1 . The asphalt binder studied is classified as Petroleum Asphalt Cement 50/70, or CAP 50/70, according to Brazilian Standards (Silva, 2005). The results of penetration, softening point, Brookfield viscosity, ductility (25 ${ }^{\circ} \mathrm{C}$ ), solubility in trichroloroethylene, flash point, and relative density are according to the literature data (Silva, 2005).

Table 1. Characterization of the bitumen.

\begin{tabular}{|c|c|c|c|}
\hline & $\begin{array}{c}\text { ASTM } \\
\text { Method }\end{array}$ & Result & Unit \\
\hline Penetration & D 5 & 50 & $\begin{array}{c}0.1 \\
\mathrm{~mm}\end{array}$ \\
\hline Softening point & D 36 & 49.5 & $\stackrel{\circ}{C}$ \\
\hline $\begin{array}{l}\text { Brookfield viscosity (135 } \\
\stackrel{\circ}{ } \text { C) }\end{array}$ & D 4402 & 356 & $\mathrm{mPa} . \mathrm{s}$ \\
\hline $\begin{array}{l}\text { Brookfield viscosity } \\
(150 \stackrel{\circ}{ })\end{array}$ & D 4402 & 179 & $\mathrm{mPa} . \mathrm{s}$ \\
\hline $\begin{array}{l}\text { Brookfield viscosity } \\
\left(177^{\circ} \mathrm{C}\right)\end{array}$ & D 4402 & 66 & $\mathrm{mPa} . \mathrm{s}$ \\
\hline Ductility $(25 \stackrel{\circ}{ } \mathrm{C})$ & D 113 & $>150$ & $\mathrm{~cm}$ \\
\hline $\begin{array}{l}\text { Solubility in } \\
\text { trichroloroethylene }\end{array}$ & D 2042 & 99.8 & $\begin{array}{c}\% \\
w t / w t\end{array}$ \\
\hline Flash point & D 92 & 274 & of \\
\hline Relative density $20 / 4$ o $\mathrm{C}$ & D 70 & 1.011 & - \\
\hline
\end{tabular}




\subsection{RTFOT}

The binder before and after the RTFOT was analyzed by using infrared spectroscopy and the results have been reported elsewhere (Lins et al., 2008). The differences between the spectra are evident mainly in the region of vibration of $\mathrm{C}-\mathrm{H}$, $\mathrm{C}=\mathrm{O}$ and $\mathrm{O}-\mathrm{H}$ bonds. The area of bands associated with the $\mathrm{C}=\mathrm{O}$ groups of carboxylic acids and ketones $\left(1635 \mathrm{~cm}^{-1}\right)$ and to stretching of $\mathrm{O}-\mathrm{H}$ groups of alcohols and carboxylic acids $\left(3436.9 \mathrm{~cm}^{-}\right.$ $\left.{ }^{1}\right)$ increased as compared to the total area of bands. The area of bands relative to the asymmetric stretching of $\mathrm{C}-\mathrm{H} \quad\left(2923.8 \mathrm{~cm}^{-1}\right)$ decreased. Oxidation of aliphatic groups generating compounds such as carboxylic acids and ketones occurred during the RTFOT (Tia et al., 1994).

\subsection{Ageing test}

The hot mix asphalt samples after ageing showed visible alterations in their surface such as cracks and white spots (Figure 1).

Scanning electron microscopy (SEM) is adequate for analyzing heterogeneous surfaces with high roughness. The SEM micrographs of samples without ageing and after ageing for $2000 \mathrm{~h}$ are shown in Figures 2 and 3, respectively.

The porosity was evaluated as $10 \%$ for samples without ageing and $45 \%$ for samples aged for 2000 hours. The ageing causes a decrease in viscosity of the binder due to oxidation, followed by the pullout of the filler of the concrete causing the beginning of cracking.

The semi-quantitative chemical analysis of the samples before and after ageing, determined by $X R F$, identified high contents of silicon and oxygen,

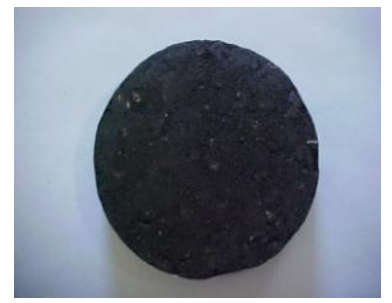

(I)

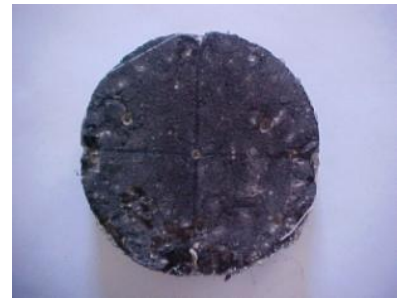

(II)
Figure 1. Hot mix asphalt samples before ageing (I) and after 2000 hours of exposure in the weathering chamber (II).

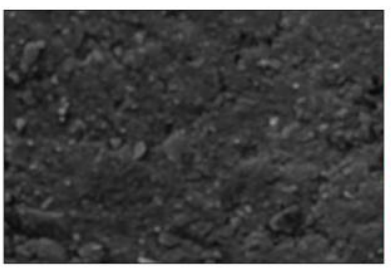

(I)

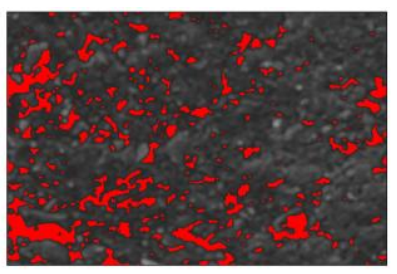

(II)
Figure 2. SEM micrographs of hot mix asphalt samples without ageing (I) and the SEM image treated by using the Quantikov software (II).

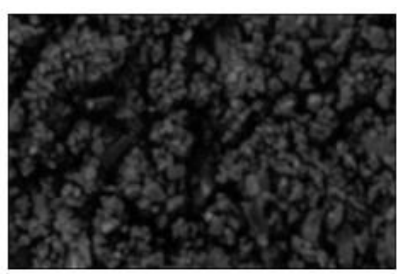

(I)

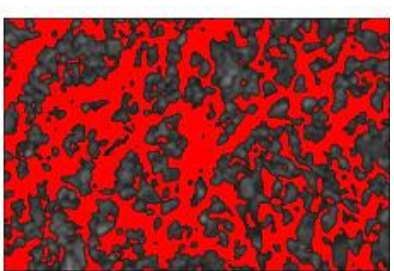

(II)
Figure 3. SEM micrographs of hot mix asphalt sample after ageing for 2000 hours (I) and the SEM image treated by using the Quantikov software (II).

a medium content of aluminum, iron and magnesium, low contents of potassium, calcium, titanium, sulfur, phosphorus and sodium, and traces of zirconium, strontium, zinc, tungsten, copper, nickel, cobalt, manganese, chromium, barium and chlorine. The HMA sample aged for $2000 \mathrm{~h}$ presented rubidium and yttrium. The binder is a residue of petroleum refining process, and the presence of several different elements is expected. In addition, the asphalt mix is composed by gravel, washed sand and stone powder which can also contain different contaminants. The presence of rubidium and yttrium in the sample aged for 2000 $h$ only highlights the diversity of elements present in the samples of hot mix asphalt.

The occurrence of a molecular organization after ageing for 2000 hours in the weathering chamber was not verified by using X-ray diffraction (Figures 4 and 5). The molecular organization could result in the appearance of new peaks in spectra of aged samples. The spectrum of HMA samples before ageing showed three peaks with a higher intensity (higher than 3600 counts), which are associated with quartz $\left(\mathrm{SiO}_{2}\right)$, biotite $\{\mathrm{K}(\mathrm{Mg}$, $\left.\left.\mathrm{Fe}^{2+}\right)_{3}\left[\mathrm{AlSi}_{3} \mathrm{O}_{10}(\mathrm{OH}, \mathrm{F})_{2}\right]\right\}$, albite $\left(\mathrm{NaAlSi}_{3} \mathrm{O}_{8}\right)$, and microcline $\left(\mathrm{KAISi}_{3} \mathrm{O}_{8}\right)$. 


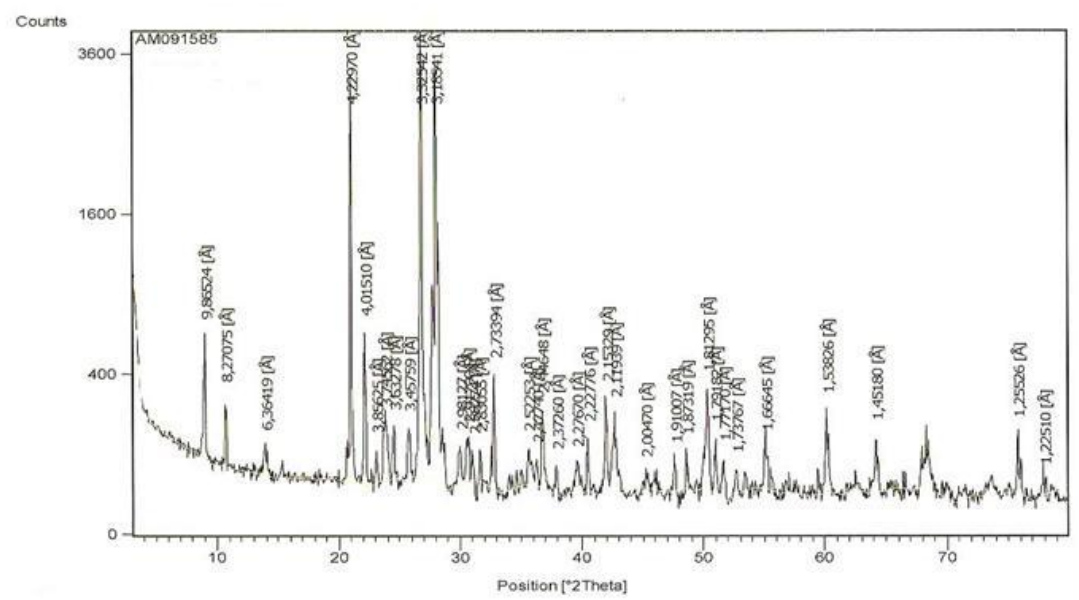

Figure 4. XRD diffractogram of the sample without ageing.

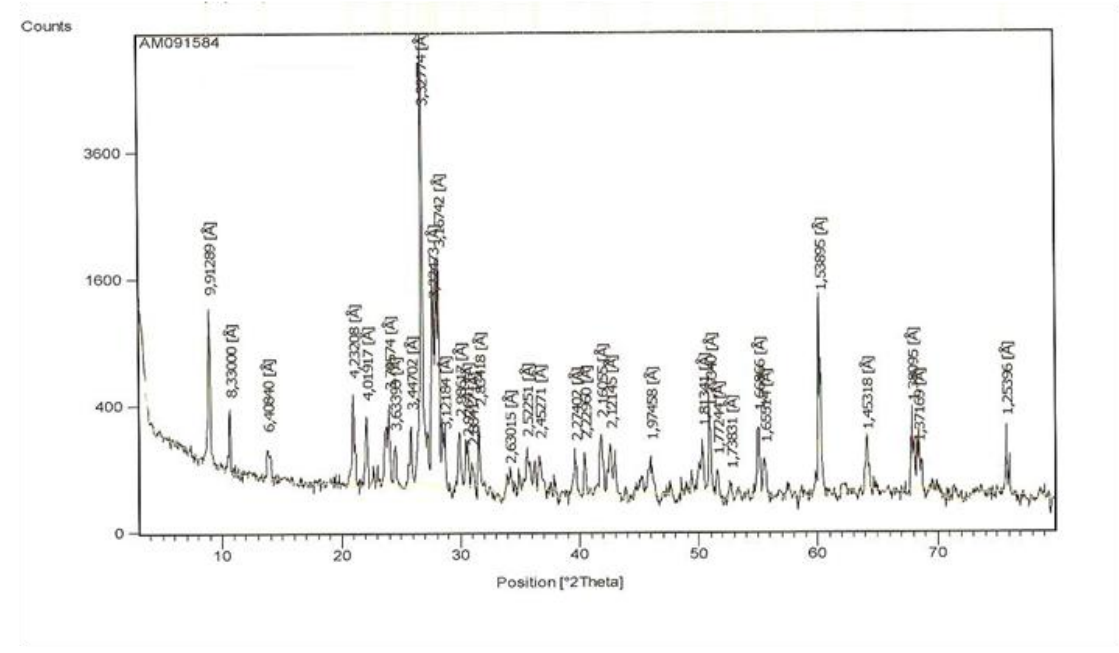

Figure 5. XRD diffractogram of the sample after 2000 hours of exposure in the weathering chamber.

The spectrum of samples after ageing for 2000 hours showed one peak with intensity higher than 3600 counts, which is associated with biotite and quartz phases. Amphibole groups could also be identified in both spectra. The chemical formula of amphibole is $\quad \mathrm{AX}_{2} \mathrm{Z}_{5}\left[(\mathrm{Si}, \mathrm{Al}, \mathrm{Ti})_{8} \mathrm{O}_{22}\right](\mathrm{OH}, \mathrm{F}, \mathrm{Cl}, \mathrm{O})_{2}$, where " $A$ " is $\mathrm{Na}, \mathrm{K}, \mathrm{Ca}$, or $\mathrm{Pb}$; " $\mathrm{X}$ " is $\mathrm{Li}, \mathrm{Na}, \mathrm{Mg}, \mathrm{Fe}$, $\mathrm{Mn}$, or $\mathrm{Ca}$; and " $\mathrm{Z}$ " is $\mathrm{Li}, \mathrm{Na}, \mathrm{Mg}, \mathrm{Fe}, \mathrm{Mn}, \mathrm{Zn}, \mathrm{Co}, \mathrm{Ni}$, $\mathrm{Al}, \mathrm{Cr}, \mathrm{V}, \mathrm{Ti}$, or $\mathrm{Zr}$.

Table 2. Bands observed in spectra of hot mix asphalt samples.

\begin{tabular}{lll}
\hline Bands $\left(\mathrm{cm}^{-1}\right)$ & Attribution & Observations \\
\hline $1100-1000$ & $\mathrm{Si}-\mathrm{O}-\mathrm{Si}$ Stretching & Silica \\
$\sim 1375$ & $\mathrm{CH}_{3}$ Deformation & Aliphatic \\
$\sim 1458$ & $\mathrm{CH}_{3}, \mathrm{CH}_{2}$ Deformation & Aliphatic \\
$\sim 1636$ & & Carboxylic acid, ketones \\
& $\mathrm{C}=\mathbf{O}$ Stretching & \\
$\sim 2850$ & $\mathrm{C}-\mathrm{H}\left(\mathrm{CH}_{2}\right)$ Symmetric stretching & Aliphatic hydrogen \\
$\sim 2870$ & $\mathrm{C}-\mathrm{H}\left(\mathrm{CH}_{3}\right)$ Symmetric stretching & Aliphatic hydrogen \\
$\sim 2923$ & $\mathrm{C}-\mathrm{H}\left(\mathrm{CH}_{3}, \mathrm{CH}_{2}\right)$ Asymmetric stretching & Aliphatic hydrogen \\
$\sim 2955$ & $\mathrm{C}-\mathrm{H}\left(\mathrm{CH}_{3}\right)$ Asymmetric stretching & Aliphatic hydrogen \\
$\sim 3450$ & $\mathrm{O}-\mathrm{H}$ Stretching & Alcohol, carboxylic acid, phenol \\
$\sim 3019,1215$ and 758 & $\mathrm{C}-\mathrm{H}$ Stretching and deformation, & Chloroform \\
& $\mathrm{C}-\mathrm{Cl}$ deformation & \\
\hline
\end{tabular}




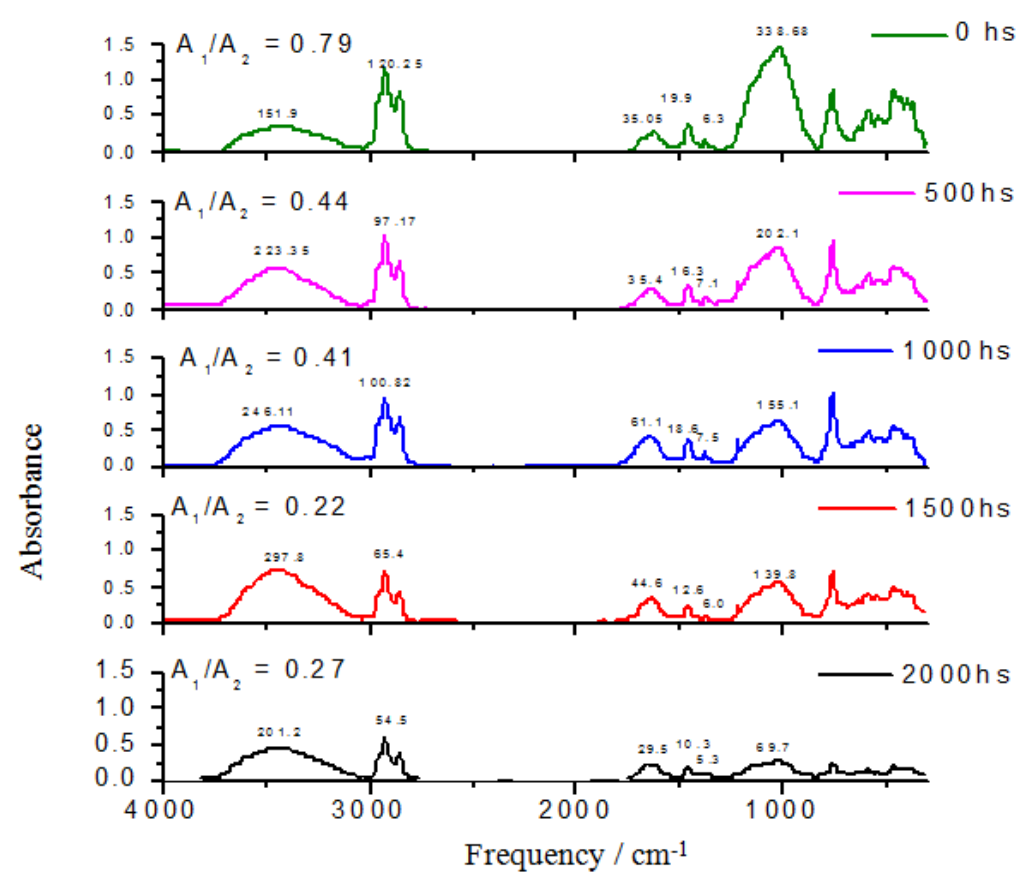

Figure 6. FTIR spectra of binder compounds extracted from the hot mix asphalt samples before and after 500, 1000,1500 , and 2000 hours of exposure in the weathering chamber; region: $400-4000 \mathrm{~cm}^{-1}$; linear baseline.

The intensity of peaks at $4.22 \AA$ and at $3.18 \AA$, which are associated to quartz and albite phases, decreased after ageing of samples for 2000 hours. FTIR analysis showed that vibrations related to the silica group decreased with the ageing process

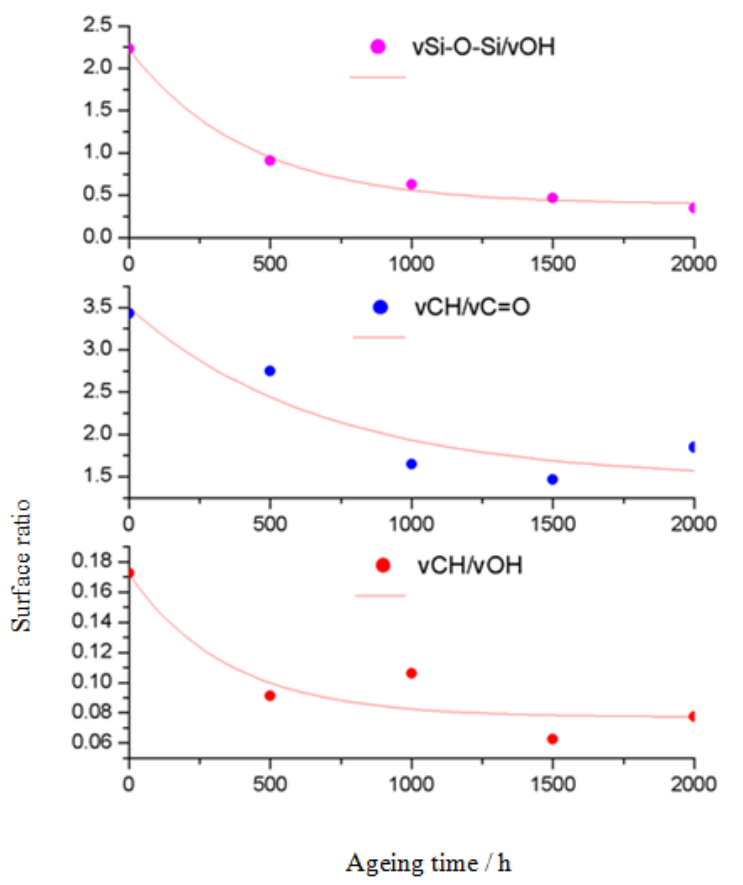

Figure 7. Surface ratio of $\mathrm{Si}-\mathrm{O}-\mathrm{Si} / \mathrm{OH}, \mathrm{CH} / \mathrm{C}=\mathrm{O}$, and $\mathrm{CH} / \mathrm{OH}$ bands for samples without ageing and after $500,1000,1500$, and 2000 hours of exposure in the weathering chamber.
(Figure 6). The presence of an amorphous fraction was identified in samples before and after ageing.

The bands associated with the binder were in the range of 4000 to $1300 \mathrm{~cm}^{-1}$, as indicated by the FTIR spectra shown in Figure 6. The lower frequency bands are related to silicon materials.

The binder was extracted from the aged samples by using $\mathrm{CHCl}_{3}$ and applied as a thin film on a $\mathrm{KBr}$ cell. Table 2 shows the bands observed.

An increase in the area of bands associated with $\mathrm{C}=\mathrm{O}$ and $\mathrm{O}-\mathrm{H}$ groups in relation to the area of $\mathrm{C}-\mathrm{H}$ bands could be observed (Figure 7). Vibrations related to the silica group were identified, and decreased with the ageing process. Ageing can cause the weakness of bonds between the binder and silica, which occurs as a covalent bond.

Oxidation of binder produces free radicals which generate hydro peroxides, and intermediary products such as ketones, alcohols, acids, phenols, aldehydes, and a higher fraction of asphaltenes. Asphalt binder is a colloidal dispersion of asphaltenes in an oil medium of maltenes. Oxidation generally causes the increase of asphaltenes content and the increase of hardness of asphalt (Ruan et al., 2003). 


\section{CONCLUSION}

The hot mix asphalt samples after ageing showed signs of degradation in the form of visible alterations in their surface, such as cracks and white spots. The FTIR results indicated that an oxidation process of binder samples occurred during exposure to xenon radiation, with the increase in the area of bands associated with $\mathrm{C}=\mathrm{O}$ and $\mathrm{O}-\mathrm{H}$ groups as compared with the area of $\mathrm{C}-\mathrm{H}$ bands. The porosity of hot mix asphalt samples increased from $10 \%$, for samples without ageing, to $45 \%$ for samples aged for 2000 hours. These results indicate that exposure of asphalt pavement to solar radiation increases the porosity of hot mix asphalt and accelerates the pavement degradation, causing the removal of filler fines and an increase in the probability of crack initiation. Addition of substances that promote solar protection in the asphalt binder can contribute to minimize the degradation by solar radiation.

\section{ACKNOWLEDGMENTS}

The authors would like to thank the Department of Highways of Minas Gerais, the Foundation of Research Support of the State of Minas Gerais, FAPEMIG, and the National Council of Scientific and Technological Development, CNPq.

\section{REFERENCES}

Airey, G. State of the Art Report on Ageing Test Methods for Bituminous Pavement Materials. International Journal of Pavement Engineering, v. 4(3), p. 165-76, 2003. doi:10.1080/1029843042000198568

Arenas, L.T.; Gay, D.S.F.; Moro, C.C.; Dias, S.L.P.; Azambuja, D.S.; Costa, T.M.H.; Benvenutti, E.V.; Gushikem, Y. Brilliant yellow dye immobilized on silica and silica/titania based hybrid xerogels containing bridged positively charged 1,4diazoniabicyclo[2.2.2]octane: Preparation, characterization and electrochemical properties study. Microporous and Mesoporous Materials, v.112 (1-3), p. 273-283, 2008.

doi:10.1016/j.micromeso.2007.09.043

Bernucci, L.B.; Motta, L.M.G.; Ceratti, J.A.P.; Soares, J.B. Pavimentação Asfáltica. Formação
Básica para Engenheiros. Rio de Janeiro: PETROBRAS, ABEDA, $2008.501 \mathrm{p}$.

Cortizo, M.S.; Larsen D.O.; Bianchetto, H.; Alessandrini, J.L. Effect of the thermal degradation of SBS copolymers during the ageing of modified asphalts. Polymer Degradation and Stability, v. 86, p. 275-282, 2004.

doi:10.1016/i.polymdegradstab.2004.05.006

Durrieu, F.; Farcas, F.; Mouillet, V. The influence of UV aging of a Styrene/Butadiene/Styrene modified bitumen: Comparison between laboratory and on site aging. Fuel, v. 86, p. 1446-51, 2007. doi:10.1016/j.fuel.2006.11.024

Huet, J . Spectrographie infrarouge et composition chimique globale des bitumes em cours dévolution dans des sections routières experimentales. Belgique: Centre des recherches routières, 1998. 100 p. (in French)

Leite, L.F.M. Estudos de Preparo e Caracterização de Asfaltos Modificados por polímero. 249f. Tese de Doutorado. Instituto de Macromoléculas Eloisa B. Mano, Universidade Federal do Rio de Janeiro, Rio de Janeiro, 1999. (in Portuguese)

Lins, V. F. C. ; Araújo, M. F. A. S. Envelhecimento acelerado no concreto betuminoso usinado a quente -Simulação da Radiação Solar. In: 19o Encontro de Asfalto, 2008, Rio de Janeiro, Anais do 190 Encontro de Asfalto, Rio de Janeiro, Instituto Brasileiro do Petróleo -IBP, 2008. p. 1-10. (in Portuguese)

Lins, V.F.C. ; Araujo, M.F.A.S. ; Yoshida, M.I. ; Ferraz, $\mathrm{V}$; Andrada, $\mathrm{D}$; Lameiras, $\mathrm{F}$. Photodegradation of hot-mix asphalt. Fuel, v. 87, p. 3254-3261, 2008. doi:10.1016/i.fuel.2008.04.039

Ruan, V.; Davison, R.R.; Glover, C.J. The effect of long-term oxidation on the rheological properties of polymer modified asphalts. Fuel, v.82, p.17631773, 2003. doi:10.1016/50016-2361(03)00144-3

Silva, L. S. Contribuição ao estudo do envelhecimento de ligantes asfálticos. Influência da adição de polímeros e comportamento frente a radiação UV. Tese de Doutorado. Universidade Federal do Rio Grande do Sul, 2005. (in Portuguese)

Tia, M.; Ruth, B.; Huang, S.C.; Chiu, C.T.; Richardson, D. Improved asphalt cement specifications to ensure better performance. Final Report U. F. Project 4910450434012, Department of Civil Engineering, College of Engineering 
University of Florida, USA, 1994.

Tonial, I.A. Influência do Envelhecimento do Revestimento Asfáltico na Vida de Fadiga de Pavimentos. 244f. Dissertação de Mestrado. Programa de Pós-graduação de Engenharia Química, Universidade Federal do Rio de Janeiro, 2001. (in Portuguese)

Vasconcelos, D. C. L.; Campos, W. R.; Vasconcelos, V.; Vasconcelos, W. L. Influence of process parameters on the morphological evolution and fractal dimension of sol-gel colloidal silica particles. Materials Science and Engineering A, v. 334 (1-2), p. 53-58, 2002. doi:10.1016/S09215093(01)01762-2

Whiteoak, D. SHELL Bitumen Handbook. Chertsey: Shell Bitumen, 1990. 454 p. 